Kumawula, Vol. 2, No.2, Agustus 2019, Hal 117 - 128

DOI:http://10.24198/kumawula.v1i3.23462

ISSN 2620-844X (online)

Tersedia online di http://jurnal.unpad.ac.id/kumawula/index

\title{
PELATIHAN ETIKA BERBAHASA BAGI SISWA UNTUK MENINGKATKAN KETERAMPILAN BERKOMUNIKASI DI MEDIA SOSIAL
}

\author{
Zubaidah Nasution ${ }^{1}$, Agustinus Kismet Nugroho Jati ${ }^{2}$, Shinta Setia ${ }^{3}$ \\ 1,2,3 STIE Perbanas Surabaya \\ 1'zubaidah@perbanas.ac.id, ${ }^{2}$ agustinus@perbanas.ac.id, ${ }^{3}$ shinta.setia@perbanas.ac.id
}

\begin{abstract}
ABSTRAK
Penggunaan internet dengan smartphone melalui hasil survei mengungkapkan bahwa rata-rata pengakses internet Indonesia berasal dari smartphone atau sekitar 67,2 juta atau 50,7 persen. Penggunaan internet tidak hanya digunakan oleh kalangan dewasa atau mahasiswa tetapi siswa sekolah (SMP,SMA) sudah banyak yang menggunakan internet. Penggunaan akses internet lebih banyak digunakan untuk media sosial (facebook, instagram dll), tetapi bagi siswa SMA akses internet belum digunakan secara baik dalam berkomentar atau menulis pada media sosial tidak menunjukkan etika komunikasi yang baik. Tujuan pengabdian masyarakat ini siswa SMA memiliki keterampilan penguasaan penggunakaan bahasa dan perilaku dalam menggunakan media sosial. Pada target pengabdian ini yang dilakukan di sekolah SMA Dharma Wanita Surabaya yakni terciptanya lingkungan sekolah yang beretika siswa degan mengetahui etika dari penggunaan media sosial khususnya etika dalam membuat status, komen dan membagikan video. Target lainnya siswa Sekolah Menengah Atas Dharma Wanita Surabaya diharapkan memiliki keterampilan dalam berbahasa dan berperilaku menggunakan media sosial. Metode pelaksanaan pengabdian dengan cara mentransfer ilmu tentang etika berkomunikasi di media sosial dengan cara memberikan pelatihan, transfer ilmu yang dilakukan yakni etika menggunakan short message servive (SMS), etika menggunakan email, etika menggunakan media sosial resmi seperti facebook, instagram, twitter dan lain-lain dan etika bertelepon. Berdasarkan hasil tanya jawab pembicara dengan siswa SMA Dharma Wanita Surabaya kemampuan siswa dalam beretika sudah mulai dilakukan, hal ini ditunjukkan dari postingan video siswa melalui instagram dan tanggapan atau komentar siswa ketika diberi kasus yang berkaitan dengan tindak pidana ITE.
\end{abstract}

Kata Kunci : Etika Berkomunikasi, Media Sosial

\section{LANGUAGE ETHICS TRAINING FOR STUDENTS IN ORDER TO INCREASE THEIR COMMUNICATION CAPABILITIES IN SOCIAL MEDIA}

\begin{abstract}
Based on a a survey conducted on internet use with smartphones, the average internet user in Indonesia comes from smartphones, which is around 67.2 million or 50.7 percent. Internet users are not only adults, but also students from middle and high schools have also widely used the internet. The internet is widely used to access social media such as Facebook, Instagram, and etc. However, internet
\end{abstract}


users particularly high school students do not use their internet access properly. For instance, they put a comment or write something in social media which does not indicate good communication ethics. This community service aims to aid high school students in order to achieve a more comprehensive understanding of language usage and to control their behavior through social media. The target of this community service conducted in Dharma Wanita High School Surabaya is to create an ethical school environment. In this case, students are expected to have good ethics in using social media especially while writing a status, commenting, and video sharing. Moreover, students of Dharma Wanita High School Surabaya are assumed to possess good language skills and behavioral control when using social media. The implementation of this community service is done by transferring knowledge about communication ethics in social media such as providing training. Transfer of knowledge includes ethics of using short message service (SMS), email, chat, and ethics of using official social media such as Facebook, Instagram, Twitter and others and telephone ethics as well. According to the question and answer session with the students of Dharma Wanita High School Surabaya, the community service seems to have been implemented. This is shown from their videos postings and responses on Instagram or their comments when they were given cases relating to ITE criminal acts.

Keywords: Communication Ethics, Social Media

\section{PENDAHULUAN}

Perkembangan internet di Indonesia menjadi sangat cepat. Hal ini berjalan seiring dengan bertambahnya jumlah penduduk di Indonesia. Data menunjukkan, pada tahun 2013 jumlah pengguna internet di Indonesia mencapai 63 juta orang. Berdasarkan angkat tersebut 95\% penduduk Indonesia menggunakan internet untuk mengakses media sosial (Kominfo, 2013). Ditjen Informasi dan Komunikasi Publik (IKP) mengungkapkan bahwa situs jejaring sosial yang paling banyak diakses adalah Facebook dan Twitter. Pada Tahun 2016, pengguna internet di Indonesia meningkat sebesar 110,63\% dari tahun 2013 atau mencapai 132,7 juta pengguna. Jumlah penduduk Indonesia pada tahun 2016 sebanyak 256,2 juta jiwa (Asosiasi Penyelenggara Jaringan Internet Indonesia (APJII, 2016). Hal tersebut berarti bahwa sebanyak 51,79\% atau lebih dari separuh dari jumlah penduduk di Indonesia yang sudah menggunakan komunikasi elektronik.

Selain perkembangan infrastruktur dan kemajuan teknologi yang berkembang pesat, kemudahan untuk mendapatkan perangkat genggam juga menjadi salah satu hal yang mendorong peningkatan jumlah pengguna internet. Hasil survei mengungkapkan bahwa ratarata pengakses komunikasi elektronik Indonesia berasal dari perangkat genggam sekitar 67,2 juta atau 50,7 persen (Kompas Tekno, 2016). Survei yang dilakukan pada bulan April 2016 oleh lembaga Polling Indonesia dan APJII dengan jumlah pengguna internet sebanyak 132,7 juta jiwa. Di bawah ini tabel pengguna internet berdasrakan umur, profesi dan jenis media sosial yang digunakan. 
Tabel 1 Pengguna Media Berdasarkan Umur

\begin{tabular}{|c|c|}
\hline Umur & Persentasi \\
\hline $10-24$ & $18,4 \%$ \\
\hline $25-34$ & $24,4 \%$ \\
\hline $35-44$ & $29,2 \%$ \\
\hline $45-54$ & $18 \%$ \\
\hline$>55$ & $10 \%$ \\
\hline
\end{tabular}

Tabel 2 Pengguna Media Berdasarkan Profesi

\begin{tabular}{|c|c|}
\hline Profesi & Persentasi \\
\hline Pekerja/wiraswasta & $62 \%$ \\
\hline Pelajar & $6,3 \%$ \\
\hline
\end{tabular}

Tabel 3 Pengguna Media Berdasarkan Jenis Media Sosial

\begin{tabular}{|c|c|}
\hline Media Sosial & Persentasi \\
\hline Facebook & $54 \%$ \\
\hline Instagram & $15 \%$ \\
\hline Youtube & $11 \%$ \\
\hline Twitter & $7,2 \%$ \\
\hline
\end{tabular}

Berdasarkan infromasi tersebut kita dapat menyimpulkan bahwa rata-rata pengguna internet banyak digunakan untuk mengakses media sosial. Dengan media sosial pengguna dapat melakukan apapun seperti, menggunggah dan membagikan foto dan video hingga berkomentar. Setiap warga negara memang dijamin oleh Undang-Undang untuk menyampaikan pendapat. Akan tetapi belakangan ini hak tersebut sering digunakan secara berlebihan, artinya sering terlontar kata-kata ataupun kalimat yang berkaitan dengan isu sara, agama dan ras serta menebar kebencian hingga menggunakan kata-kata kotor yang tidak sesuai untuk digunakan dalam berkomunikasi.

Pemerintah melihat serius permasalahan ini, karena banyak kasus yang melibatkan siswa maupun guru yang terkait dengan etika menggunakan media sosial. Seperti kasus Seorang guru honorer SMK dan pegawai kontrak badan kepegawaian dan pengembangan SDM Buleleng Bali (BKPSDM) mengajak sesorang siswi SMK untuk berhubungan intim bertiga (tribunnews.com, 2018). Pada kondisi yang sama banyak siswa sekolah yang juga terkena sanksi akibat "kurang beretikanya" mereka dalam menggunakan media sosial. Contohnya adalah kasus yang menjerat tiga orang siswa SMA Negeri Bungaraya di Siak, Riau. Tiga orang siswa ini dikeluarkan dari sekolah akibat status yang mereka tulis di salah satu media sosial (facebook). Adapun status yang mereka tuliskan itu berbunyi "Kita terlambat dihukum, guru telat lewat saja." dengan 
menggunakan komentar-komentar yang tidak baik (Lestari, BBC Indonesia, 2014). Tidak dapat dipungkiri, bahwa saat ini, siswa Sekolah Menengah Pertama (SMP) bahkan Sekolah Dasar (SD) banyak yang sudah menggunakan smartphone. Oleh karena itu, kita menyadari bahwa, pendidikan di sekolah tidak hanya mengajarkan ilmu-ilmu pengetahuan yang sifatnya sains saja, melainkan juga harus mengajarkan bagaimana bersikap dan beretika khususnya dalam menggunakan media sosial. Hal ini senada dengan hasil wawancara dan hasil kuesioner yang disebarkan dan dilakukan dengan Kepala Dinas Pendidikan Kota Surabaya

Berdasarkan hasil wawancara dan survei berupa pengisian kuesioner didapat kesimpulan bahwa, sebaiknya perangkat sekolah, khususnya guru dan siswa mendapatkan pengetahuan mengenai etika dalam menggunakan media sosial. Menurut guru sekolah SMA Kota Surabaya hal ini perlu dilakukan mengingat banyaknya kasus yang menjerat siswa maupun guru akibat pengiriman gambar ataupun komentar mereka di media sosial. Ditambah lagi dengan kemajuan teknologi yang semakin memperluas akses dan kebebasan berbicara sekaligus menipiskan etika bagi penggunanya. Berdasarkan data sekolah SMA Dharma Wanita, jumlah guru yang terdaftar di Sekolah Menengah Atas Dharma Wanita Surabaya sebanyak 21 orang, sedangkan jumlah siswa, mulai dari kelas 7, 8 hingga 9 berjumlah 233 siswa. Melihat data tersebut dan realita serta kebutuhan yang diperlukan oleh sekolah, maka tim pendidik STIE Perbanas Surabaya melakukan kegiatan Pengabdian Masyarakat yang diperuntukkan bagi guru dan siswa Sekolah Menengah Atas Dharma Wanita Surabaya.

Etika berasal dari kata ethikus dan dalam bahasa Yunani disebut ethicos yang berarti kebiasaan norma-norma, nilai-nilai, kaidah-kaidah dan ukuran-ukuran baik dan buruk tingkah laku manusia. Jadi, etika komunikasi adalah norma, nilai, atau ukuran tingkah laku baik dalam kegiatan komunikasi di suatu masyarakat. Menurut Richard J (Karimah dan Wahyudin, 2010) etika merupakan mencoba untuk meneliti tingkah laku manusia yang dianggap merupakan cerminan dari apa yang terkandung dalam jiwanya atau dalam hati nuraninya. Ketiga pengertian etika berikut berkaitan dengan perlunya etika komunikasi dalam menggunakan media sosial.

a. Etika Deskriptif yaitu etika yang bersangkutan dengan nilai dan ilmu pengetahuan yang membicarakan masalah baik dan buruknya tingkah laku manusia dalam kehidupan bermasyarakat.

b. Etika Normatif yaitu etika yang sering dipandang sebagai suatu ilmu yang mengadakan ukuran-ukuran atau norma yang dapat dipakai untuk menanggapi atau menilai 
perbuatan dan tingkah laku seseorang dalam bermasyarakat. Etika ini berusaha mencari ukuran umum bagi baik dan buruknya tingkah laku

c. Etika Kefilsafatan yaitu analisa tentang apa yang dimaksudkan bilamana mempergunakan predikat-predikat kesusilaan. Dalam etika ini berhubungan dengan norma. Norma adalah peraturan atau pedoman hidup tentang bagaimana seharusnya.

Komunikasi secara terminologis merujuk pada adanya proses penyampaian suatu pernyataan oleh seseorang kepada orang lain. Jadi dalam pengertian ini yang terlibat dalam komunikasi adalah manusia. Menurut Ruben dan Steward (2005) mengenai komunikasi manusia yaitu:

Human communication is the process through which individuals -in relationships, group, organizations and societies-respond to and create messages to adapt to the environment and one another.

Menurut (Weaver dalam Marhaeni Fajar,2009) komunikasi adalah seluruh prosedur melalui mana pikiran seseorang dapat mempengaruhi pikiran orang lainnya. Selanjutnya, menurut (Shannon dan Weaver dalam Changara, 2010) komunikasi adalah bentuk interaksi manusia yang saling pengaruh mempengaruhi satu samalainya,sengaja atau tidak di sengaja.Tidak terbatas pada bentuk komunikasi menggunakan bahasa verbal, tetapi juga dalam hal ekspresi muka,lukisan,seni dan teknologi. Secara umum tujuan komunikasi adalah mengharapkan adanya umpan balik (feedback) yang diberikan oleh lawan bicara kita, serta semua pesan yang kita sampaikan dapat diterima oleh lawan bicara kita dan adanya efek yang terjadi setelah melakukan komunikasi tersebut.

Menurut Onong Uchjana Effendy (2009) adapun beberapa tujuan komunikasi adalah sebagai berikut :

a. Supaya gagasan kita dapat diterima oleh orang lain dengan pendekatan yang persuasif bukan memaksakan kehendak.

b. Memahami orang lain, kita sebagai pejabat atau pimpinan harus mengetahui benar aspirasi masyarakat tentang apa yang diinginkannya, jangan mereka menginginkan arah ke barat tapi kita memberi jalur ke timur.

c. Menggerakkan orang lain untuk melakukan sesuatu, menggerakkan sesuatu itu dapat bermacam - macam mungkin berupa kegiatan yang dimaksudkan ini adalah kegiatan 
yang banyak mendorong, namun yang penting harus diingat adalah bagaimana cara yang terbaik melakukannya.

d. Supaya yang kita sampaikan itu dapat dimengerti sebagai pejabat ataupun komunikator kita harus menjelaskan kepada komunikan (penerima) atau bawahan dengan sebaikbaiknya dan tuntas sehingga mereka dapat mengikuti apa yang kita maksudkan.

Media elektronik secara umum, yaitu segala jenis atau format media yang hanya bisa diakses melalui internet berisikan teks, foto, video, dan suara. Dalam pengertian umum ini, media elektronik juga bisa dimaknai sebagai sarana komunikasi secara elektronik. Menurut Soeparno dan Sandra dalam (Mulawarman dan Aldila Dyas Nurfitri,2017) dunia maya seperti media sosial merupakan sebuah revolusi besar yang mampu mengubah perilaku manusia dewasa ini dengan relasi pertemanan serba dilakukan melalui medium digital -menggunakan media elektronik yang dioperasikan melalui situs-situs jejaring sosial. Realitas menjadi bersifat augmented dan maya yang harus diadaptasi dan diinte-grasikan dalam kacamata kajian psikologi sosial kontemporer yang ubiquitous (ada dimana-mana) serta pervasive (dapat menembus berbagai bidang ilmu dan kajian)

Ardianto dalam buku Komunikasi 2.0 mengungkapkan, bahwa media sosial disebut jejaring sosial bukan media massa karena media sosial memiliki kekuatan sosial yang sangat mempengaruhi opini publik yang berkembang di masyarakat. Penggalangan dukungan atau gerakan massa bisa terbentuk karena kekuatan media online karena apa yang ada di dalam media sosial, terbukti mampu membentuk opini, sikap dan perilaku publik atau masyarakat. Fenomena me-dia sosial ini bisa dilihat dari kasus Prita Mulyasari versus Rumah Sakit Omni International. Inilah alasan mengapa media ini disebut media sosial bukan media massa. (Kompas, 2009)

Efek media komunikasi massa dengan teknologi terbaru dapat memberikan beberapa efek yang tidak dapat dihindari yang diantaranya meliputi aspek kognitif, aspek afektif dan aspek behavioral. Efek kognitif terjadi bila ada perubahan pada apa yang diketahui, dipahami, atau dipersepi khalayak. Efek ini berhubungan dengan transmisi pengetahuan, ketrampilan, kepercayaan atau informasi. Efek afektif akan timbul bila bila ada perubahan pada apa yang dirasakan, disenangi atau dibenci khalayak. Efek ini ada hubungannya dengan sikap, emosi, atau nilai. Efek behavioral merujuk pada perilaku yang nyata yang dapat diamati yang meliputi pola-pola tindakan, kegiatan, atau kebiasaan berperilaku, misalnya, setelah menyaksikan wawancara seorang transmigran dengan reporter TVRI, mungkin akan diperoleh informasi 
tentang perosedur transmigrasi (efek kognitif), atau mungkin ada rasa terharu menyaksikan keberhasilan transmigran (efek afektif) sehingga kemudian mengikuti jejak langkah transmigran untuk ikut bertransmigrasi (efek behavioral) (Rachmat, 2011: 217).

Menurut Uud Wahyudin dan Kismiyati El Karimah (2010), Tren yang berkembang dalam proses komunikasi di media sosial terlihat dari begitu mudah orang menumpahkan amarah tanpa memikirkan perasaan orang lain, caci maki alias cyber bullying, saling menghujat, saling mencela, penyumbang pecahnya konflik, memojokkan dan menghakimi orang lain, dan lainlain. Media sosial sebaiknya dapat menjadi wahana untuk mendudukkan proses dialog yang sehat dalam berkomunikasi agar terwujud harmonisasi. Media sosial sejatinya menempatkan proses dialog yang memberikan ruang atas semakin meningkatnya kesejahteraan sebuah komunitas masyarakat sekaligus menjadi platform dalam rangka menciptakan diseminasi gagasan secara rasional dan menyejukkan

Errika Dwi Setya Watie (2011) dan Aspikom (2011) Komunikasi dalam media sosial menjadi lebih kompleks. Dua level komunikasi melebur menjadi satu. Komunikasi interpersonal melebur dengan komunikasi massa. Pada saat orang mengunggah sesuatu, dan terjadi interaksi dengan pihak lain, maka komunikasi interpersonal terjadi, dan disaat yang sama terjadi juga komunikasi massa, sebab apapun yang diunggah bisa langsung dinikmati dan dilihat khalayak banyak. Kebebasan berpendapat, keleluasaan berbagi yang ditawarkan media sosial hendaknya bisa disikapi secara bijak oleh penggunanya. Dengan tetap berpegang pada etika komunikasi yang kuat, maka kendali diri niscaya akan bisa didapatkan. Melalui komunikasi di media sosial memang menjadi lebih luas dan leluasa, namun keleluasaan tersebut haruslah tetap terkendali, agar manfaat yang ada bisa dinikmati dengan lebih maksimal.

\section{METODOLOGI PENELITIAN}

Metode yang akan digunakan dalam Program Kegiatan Masyarakat ini adalah dengan cara mentransfer ilmu tentang etika berkomunikasi di media sosial dengan cara memberikan pelatihan yang terkait dengan permasalahan etika siswa dalam berkomunikasi baik dengan guru sekolah maupun melalui media sosial. Pelatihan ini akan dilakukan sebanyak dua kali, yaitu pertama khusus untuk guru Sekolah Menengah Atas Dharma Wanita Surabaya, dan pelatihan keduaa oleh siswa/siswi kelas VII dan VIII Sekolah Menengah Atas Dharma Wanita Surabaya.

Transfer ilmu yang akan dilakukan berkaitan dengan pembelajaran dan pengajaran tekait dengan etika menggunakan short message servive (SMS), etika menggunakan email, etika menggunakan chat, etika menggunakan media sosial seperti facebook, instagram, twitter dan 
lain-lain dan etika bertelepon.

Tabel 4. Metode Pelaksanaan

\begin{tabular}{|c|c|c|}
\hline Materi & Metode & Output Yang Diharapkan \\
\hline $\begin{array}{l}\text { Etika mengirim } \\
\text { Short Message } \\
\text { Servive (SMS) }\end{array}$ & $\begin{array}{l}\text { - } \text { Ceramah } \\
\text { - Tanya jawab } \\
\text { - Klinik } \\
\text { permasalahan } \\
\text { siswa di sekolah } \\
\end{array}$ & $\begin{array}{l}\text { Memahami, membedakan etika } \\
\text { dalam mengirim pesan ke guru } \\
\text { atau orang yang lebih tua dan } \\
\text { sesama teman }\end{array}$ \\
\hline $\begin{array}{l}\text { Etika } \\
\text { menggunakan } \\
\text { email }\end{array}$ & $\begin{array}{l}\text { - Ceramah } \\
\text { - Tanya jawab } \\
\text { - Klinik } \\
\text { permasalahan } \\
\text { siswa di sekolah }\end{array}$ & $\begin{array}{l}\text { Memahami, membedakan etika } \\
\text { mengirim dan membalas email ke } \\
\text { guru atau orang yang lebih tua dan } \\
\text { sesama teman }\end{array}$ \\
\hline $\begin{array}{l}\text { Etika } \\
\text { menggunakan } \\
\text { chating }\end{array}$ & $\begin{array}{l}\text { - } \text { Ceramah } \\
\text { - Tanya jawab } \\
\text { - Klinik } \\
\text { permasalahan } \\
\text { siswa di sekolah }\end{array}$ & $\begin{array}{l}\text { Memahami, membedakan etika } \\
\text { dalam chating ke guru atau orang } \\
\text { yang lebih tua dan sesama teman }\end{array}$ \\
\hline $\begin{array}{l}\text { Etika } \\
\text { menggunakan } \\
\text { media sosial resmi } \\
\text { seperti facebook, } \\
\text { instagram, twitter }\end{array}$ & $\begin{array}{l}\text { - Ceramah } \\
\text { - Tanya jawab } \\
\text { - Klinik } \\
\text { permasalahan } \\
\text { siswa di sekolah }\end{array}$ & 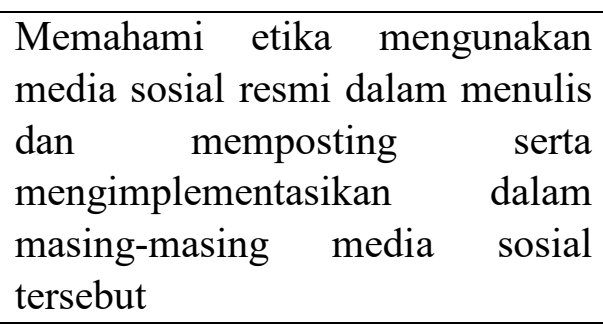 \\
\hline Etika bertelepon & $\begin{array}{l}\text { - Ceramah } \\
\text { - Tanya jawab } \\
\text { - Klinik } \\
\text { permasalahan } \\
\text { siswa di sekolah }\end{array}$ & $\begin{array}{l}\text { Memahami etika dalam menelpon } \\
\text { dan menerima telepon ke guru atau } \\
\text { orang yang lebih tua dan sesama } \\
\text { teman dan mengimplementasikan } \\
\text { pada kehidupan sehari-sehari }\end{array}$ \\
\hline
\end{tabular}

\section{HASIL DAN PEMBAHASAN}

Sebagaimana kesepakatan dengan Kepala Sekolah Menengah Dharma Wanita Surabaya maka pelaksanaan pengabdian masyarakat ini dilakukan pada hari jum'at dan 06 April 2018, Pukul : 09.00 -11.30 WIB, Lokasi Aula SMA Dharma Wanita Surabaya 197 Siswa Kelas X dan 6 Guru.

Pada pelaksaan ini, kegiatan awal difokuskan untuk memberi pengajaran beretika di media sosial berupa Undang-Undang ITE dan pengiriamn gambar baik status atau video yang berakibat pidana. Selanjutnya, siswa diarahkan untuk membuat kelompok bertujuan 
menentukan akan pasal-pasal dari kasus yang disampaikan pemateri sedangkan sebagian siswa lainnya mengunggah video lingkungan sekolah melalui instagram. Video yang dikirim ke media sosial akan dinilai oleh tim pengabdian yang dibantu oleh mahasiswa sebanyak 3 orang, sedangkan siswa yang di dalam ruangan dianjurkan untuk memberi pendapat akan kasus yang telah diberikan tim. Hal ini bertujuan untuk menilai akan kemampuan siswa dalam berpendapat terhadap apa yang terjadi di media sosial sehingga dapat membagikan berita yang benar terjadi. Di bawah ini gambar penyampaian materi pengabdian masyarakat.
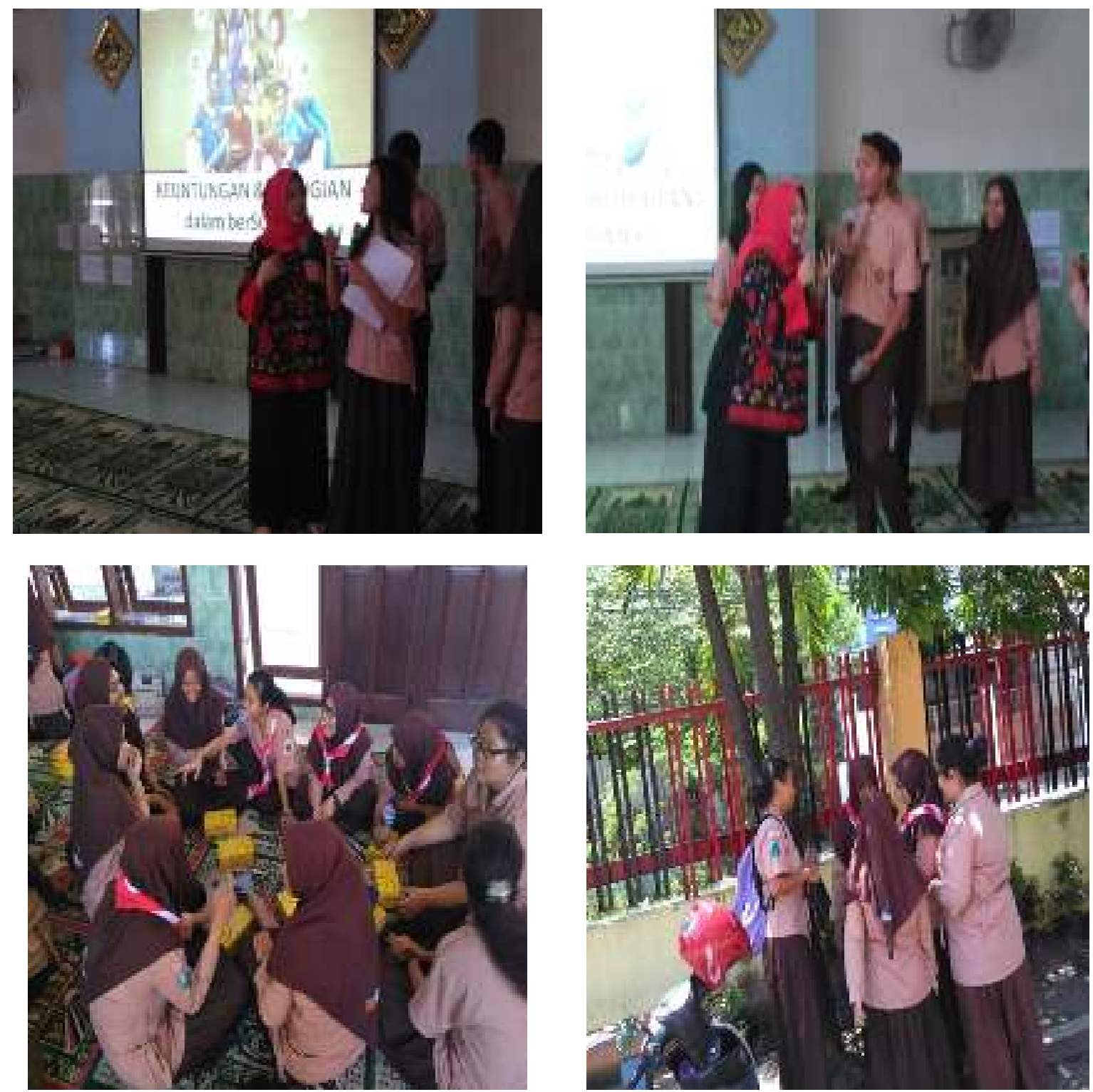

Berdasarkan hasil yang diperoleh, berikut evaluasi yang dapat disampaikan:

1. Sasaran peserta yang awalnya adalah seluruh siswa SMA Dharma Wanita dikarenakan ujian nasional dan ujian praktek sekolah pada siswa kelas 2 dan 3 SMA sehingga yang dapat mengikuti pengabdian hanya siswa kelas 1 SMA 
2. Untuk selanjutnya, sejalan dengan program sekolah dan pemerintah dalam mengurangi berita hoax maka pihak sekolah dapat membuat papan informasi tentang akan Undang-Undang ITE sehingga siswa dapat mengetahui dampak dari pengunggahan ke media sosial.

Berikut disajikan hasil evaluasi penyelenggaraan kegiatan pengabdian masyarakat:

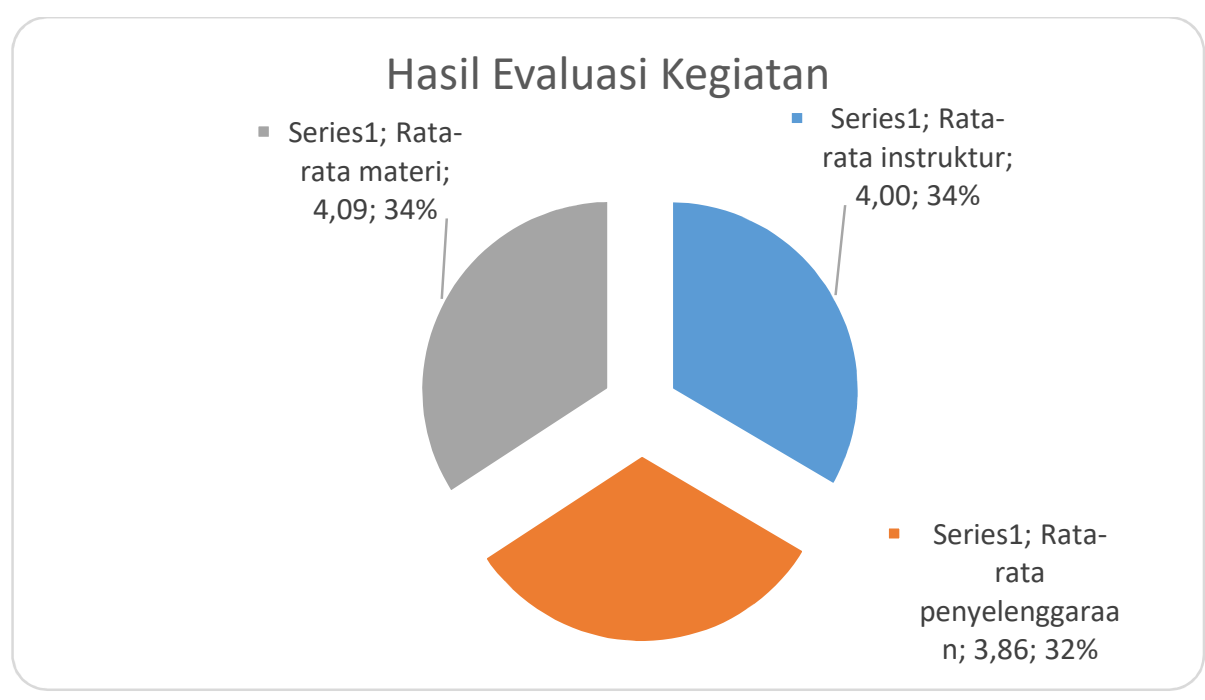

Gambar 1 Evaluasi Penyelenggaraan Kegiatan Pengabdian Masyarakat di SMA Dharma Wanita

Pada gambar 1, dapat dilihat bahwa secara keseluruhan di dapat hasil yang cukup baik, karena rata-rata keseluruhan evaluasi kegiatan sebesar 3,98. Akan tetapi, untuk hasil paling kecil terdapat dalam nilai penyelenggaraan, yaitu sebesar 3,86, dan nilai terbesar didapatkan pada hasil evaluasi materi yang diberikan, yaitu sebesar 4,09. Data tersebut menunjukkan kegiatan pengabdian ini sudah berjalan dengan baik, berdasarkan evaluasi materi yang terdiri dari kualitas materi, kemanfaatan dna kebaruan materi sudha tersampaikan sesuai dengan kebutuhan siswa sekolah menengah atas Dharma Wanita Kota Surabaya.

\section{KESIMPULAN}

Kebutuhan mengenai etika berkomunikasi ini semakin dirasakan oleh masyarakat pada umumnya dan remaja pada khususnya. Hal tersebut terjadi karena maraknya kasus yang berkaitan dengan etika berkomunikasi khususnya di media sosial. Oleh karena itu, kegiatan pengabdian ini sangatlah bermanfaat bagi remaja yang menjadi tonggak masa depan bangsa ini. Dengan dilaksanakannya kegiatan ini, para siswa dapat jelas mengetahui bagaimana beretika 
yang baik ketika berkomunikasi di media sosial, serta mengetahui hal-hal apa saja yang perlu dihindari serta dampak yang dapat ditimbulkan jika mengabaikan etika berkomunikasi di media sosial. Secara khusus, ketika berkomunikasi dengan guru misalnya, siswa menjadi tahu bagaimana cara menyampaikan maksud secara baik, ketika akan memposting sesuatu atau memberikan komentar, siswa menjadi lebih paham bagaimana memberikan caption dengan benar dan memberikan komentar yang tidak menyinggung orang lain.

Secara lebih luas, kegiatan ini juga sejalan dengan program pemerintah dalam mengatasi informasi yang tidak benar. Untuk itu, kegiatan ini tidak hanya dilakukan dengan memberikan pemahaman mengenai hal-hal yang berkaitan dengan etika berkomunikasi seperti mengirim pesan kepada guru melainkan dengan memberikan praktek secara langsung kepada siswa mengenai penggunaan berkomunikasi itu sendiri, sehingga diharapkan siswa dapat lebih memahami dan terhindar dari hal-hal yang merugikan dirinya dan orang lain. Tentu saja kegiatan ini masih banyak sekali kekurangan, oleh sebab itu kami menyarankan agar semua civitas akademik di lingkungan sekolah dapat dilibatkan, sehingga tidak hanya siswa saja yang mendapatkan pemahaman, akan tetapi semua pihak dapat turut mengambil bagian untuk berkontribusi positif dalam memberikan hal baik dalam hal etika berkomunikasi.

\section{DAFTAR PUSTAKA}

Aspikom. 2011. Komunikasi 2.0,. Yogyakarya: Mata Padi Pressindo

Asosiasi Penyelenggara Jaringan Internet Indonesia . 2016, Saatnya Jadi Pokok Perhatian Pemerintah Dan Industri. Buletin APJII, Edisi 05 Halaman 1-7

Cangara, Hafied C. 2010, Pengantar Ilmu komunikasi. Jakarta :PT.Rajagrafindo Persada

Karimah, Kismiyati, El., dan Wahyudin, Uud . 2010. Filsafat dan Etika Komunikasi: Aspek Ontologis, Epistemologis, dan Aksiologis dalam Memandang Ilmu Komunikasi. Bandung: Widya Padjadjaran.

Marhaeni Fajar, 2009, Ilmu Komunikasi Teori dan Praktek, Yogyakarta: Graha Ilmu,hlm 32 Mulawarman dan Aldila Dyas Nurfitri. 2017. Perilaku Pengguna Media Sosial beserta Implikasinya Ditinjau dari Perspektif Psikologi Sosial Terapan, Buletin Psikologi, Vol. 25, No. 1, Pp. $36-44$.

Onong Uchyana Effendy, 2009, Ilmu Komunikasi Teori dan Praktek, Bandung: Rosdakarya. 
Ruben, Brent D,Stewart, Lea P. 2005. Communication and Human Behaviour, USA: Alyn and Bacon.

Rachmat, Jalaluddin, 2011, Psikologi Komunikasi, Bandung, Remaja Rosdakarya

Wahyudin Uud, El Karimah Kismiyati, 2016, Etika Komunikasi Di Media Sosial, Prosiding Seminar Nasional Komunikasi, pp 216-224

Watie Errika Dwi Setya, 2011, Komunikasi dan Media Sosial, The Messenger, Volume III, Nomor 1, Edisi Juli, pp 69-75

https://www.bbc.com/indonesia/berita_indonesia/2014/11/141106_siswa_facebook_dikeluark an, diakses tanggal 23 januari 2018

https://nasional.kompas.com/read/2009/06/03/1112056/inilah.curhat.yang.membawa.prita.ke. penjara?page $=$ all, diakses tanggal 2 Januari 2018

https://tekno.kompas.com/read/2016/10/24/15064727/2016.pengguna.internet.di.indonesia.ca pai.132.juta, diakses tanggal 12 Januari 2018

https://kominfo.go.id/index.php/content/detail/3415/Kominfo+\%3A+Pengguna+Internet+di+I ndonesia+63+Juta+Orang/0/berita_satker, diakses tanggal 25 Februari 2018

https://jogja.tribunnews.com/2014/01/03/guru-di-klaten-ajak-muridnya-berhubungan-intim, diakses tanggal 17 februari 2018 